\title{
'My Brilliant Career'? New Organizational Forms and Changing Managerial Careers in Japan, the UK, and USA
}

\section{John Hassard, Jonathan Morris and Leo McGann}

\author{
Manchester University and Cambridge University; Cardiff University; Manchester University
}

ABSTRACT The end of the traditional management career has been heralded with supporting, albeit largely anecdotal, data. The 'old' career was set within internal labour markets in large organizations and characterized by long-term stability. The 'new' arrangements have apparently shifted responsibility from employer to employee, with careers being developed across organizations. Such change is premised on new organizational forms and is often associated with a growing sense of employee insecurity. We explore the reality of this 'new' scenario through interpretation of in-depth semi-structured interviews conducted with middle and senior human resources managers in large firms in Japan, the UK, and USA. The data indicate that most of our case study organizations had downsized and delayered, with hybrid structural forms emerging. Career prospects were diminished, with fewer vertical promotions and a greater emphasis on lateral 'development'; middle managers were generally resentful of such factors and forces. Although not directly reflective of 'Anglo-American' business practice, similar changes to career trajectories were witnessed in Japan as in the UK and USA.

Keywords: delayering, downsizing, human resources, middle managers, varieties of capitalism

\section{INTRODUGTION}

The growing interest in firm and organizational boundaries over the past decade or so is premised, to a large extent, on the emergence of so-called 'new organizational forms'. In particular, this involves purported moves from the traditional bureaucracy to a variety of innovative structures frequently based on flatter, less hierarchical formulations (Balogun and Johnson, 2004; Child and McGrath, 2001; Harris and Höpfl, 2006; Heckscher and Applegate, 1994; Josserand et al., 2006; Pettigrew and Fenton, 2000). While the empirical, conceptual and theoretical veracity of the so-called 'post-bureaucratic' organization has long been contested (Clegg, 2011; Grey and Garsten, 2001; Heckscher and Donnellon, 1994; Johnson et al., 2009; Kunda, 1992; McSweeney, 2006), there is,

Address for reprints: John Hassard, Manchester Business School, Booth Street West, Manchester M15 6PB, UK (john.hassard@mbs.ac.uk). 
nonetheless, evidence of not insignificant modifications to traditional forms in large corporations in, for example, the USA, UK, and Japan (Hassard et al., 2009; McCann et al., 2004, 2008; Morris et al., 2006, 2008). These new forms, in turn, are claimed to have major implications for various aspects of human resource management within firms, not least in respect of the breakdown of internal labour markets, increased job insecurity, and the restructuring of employee careers.

Traditional lifelong careers were themselves a product, to a degree, of the growth of the large ' $\mathrm{M}$ form' corporation in the USA, UK, Japan and elsewhere (Berggren and Nomura, 1997; Jacoby, 1985; Matanle, 2003; McKinlay, 2002), and the post-war rise of 'managerial capitalism' (Khurana, 2004, p. 52) supported by New Deal legislation (Osterman et al., 2001, pp. 58-62). Much in the way that the demise of the traditional bureaucratic form has been heralded, so has the traditional career, replaced by a new 'boundaryless' one (Arthur, 2008; Arthur and Rousseau, 1996; Arthur et al., 1999; Cappelli, 1999; Cohen and Mallon, 1999; Osterman, 1996; Peiperl et al., 2000). Changes to firms and careers are often understood in relation to the shift from managerial to investor capitalism (Khurana, 2004, pp. 52-67; Useem, 1999). Investor capitalism assumes the primacy of shareholder interests over the interests of traditional holders of power in the firm, exposing the hitherto protected careers of staff, including managers, to the risks associated with cost-control measures.

To make sense of such changes, Arthur (2008) has outlined trajectories of contemporary career research, divided into what he views, on the one hand, as issues important for career scholars, and, on the other, those important for the organization theory community. With regard to the former, an important contribution of this paper will be to offer an international comparison of contemporary managerial careers and, specifically, the interdependence between managerial careers and large firm restructuring. Of the latter, organizational interest, the paper addresses two of Arthur's (2008) main themes, focusing on individual job (in)security and a potential lack of alignment between the interests of organizations and individuals (see also O'Reilly and Pfeffer, 2000).

The aim of this paper, therefore, is to assess both the changing nature of managerial career trajectories in large organizations in the USA, UK, and Japan and, equally as important, the personal perceptions of managers in relation to experienced career changes within such organizations. The paper is structured as follows. Initially we review literature on the nature of 'new organizational forms' and the concept of the 'new career', both set within the context of organizational change and the rise of investor capitalism. The main body of the paper then presents findings from an international comparative study of managerial careers in modern work organizations. Finally, implications from these data are drawn together in the Discussion, where we advance three propositions about the nature of changing managerial careers under investor capitalism, an era characterized by the instability of large organizations and also of the managerial careers developed within them.

\section{New Organizational Forms under Investor Capitalism}

The new organizational forms paradigm emerged in the USA during the 1990s, when it was claimed that organizations were seeking to dismantle the traditional 
hierarchical-bureaucratic multi-divisional, New Deal model, characterized by multiple management layers, relatively stable career structures, and established internal labour markets (Osterman, 2009). It was argued that organizational pressures for reform included the need for greater organizational interdependence, the disembodiment of performance from asset ownership, greater business practice velocity, and knowledge-based power (Child and McGrath, 2001). Much of the dynamic behind these changes is associated with the rise of investor capitalism (Useem, 1999), in which the owners of share capital (increasingly concentrated into the hands of powerful institutional investors such as pension funds, mutual funds, and hedge funds), encourage or force the top management of firms in which they have invested to radically cut costs, increase profitability, and raise the returns on the capital employed.

In place of the traditional organizational form, then, was a new one, flatter, 'leaner', more responsive, realized through downsizing and delayering, and focusing on core activities and the 're-engineering' of business processes (Drucker, 1992; Hammer and Champy, 1993; Handy, 1995; Kanter, 1989; Peters, 1992). Some of the structural and occupational implications of this new model were increased networking, fewer managerial jobs and layers, the collapse of internal labour markets, increased workloads, reduced commitment, increased job mobility, and a reduction in loyalty (Heckscher, 1995).

Within this scenario, the downsizing of blue- and white-collar staff has been extensive in a variety of industries, especially in the USA and UK (Matanle, 2003). Authors have discussed widely the emergence of new organizational boundaries arising out of volume reductions and vertical disintegration, notably through sectoral case studies (Batt, 1996; Budros, 1999; Ezzamel et al., 2004; Farrell and Morris, 2012; Littler and Innes, 2004; MacDuffie, 1996; Scott et al., 1996). Although Japanese firms appear to be more reluctant downsizers, Usui and Colignon (1996), Ahmadjian and Robinson (2001), and McCann et al. (2010) have nevertheless reported widespread headcount reductions among large firms from the 1990s onwards, with both managers and blue-collar workers being affected.

Another major dynamic of new organizational forms is delayering. Although evidence for this practice is less abundant than for downsizing, nevertheless, it is readily found in a number of studies for the USA, UK, and Japan, as for example in research on automotives (MacDuffie, 1996), telecommunications (Batt, 1996), and manufacturing industry generally (Farrell and Morris, 2012; Hassard et al., 2009; McCann et al., 2010; Osterman, 2009). In such studies, the roles and behaviour of both junior and middle managers are found to be affected markedly by increased spans of control and heavier workload demands (see also Heckscher, 1995; Littler et al., 2003; Okubayashi, 1998; Worrall and Cooper, 2001).

Among the organizational implications of downsizing and delayering are potentially an end to job security, fewer promotion opportunities, more open labour markets, and changing career patterns. But how do these organizational dynamics directly affect managerial work? The US literature points to greater work intensification and reduced job security (Batt, 1996; Heckscher, 1995; Jacoby, 2005), but there are exceptions to the view that managerial careers are heading for extinction (Jacoby, 1999). The UK 
literature also reflects mixed results, with some authors suggesting intensified work regimes, greater insecurity, and poorer job prospects (Grimshaw et al., 2002), while others are more sanguine about the future for managerial work (Dopson and Stewart, 1990). In a well-known Europe-wide study of new organizational forms in the 1990s, Pettigrew and Fenton (2000) found major shifts in operational processes, IT investment levels, and HRM systems in line with and in support of structural changes. Tengblad (2006), meanwhile, in a comparative replication of Mintzberg's (1973) study 'thirty years on', noted both continuity and change in the managerial work of senior executives. Despite a number of comparative differences in relation to workload and informationgiving, Tengblad argued that claims for the emergence of 'radically different' managerial work were 'much exaggerated'.

The evidence for 'new' organizational forms and thus whether genuinely 'radical' transformation has occurred is therefore questionable (Alvesson and Thompson, 2005; Farrell and Morris, 2003; Hales, 1999a, 1999b, 2002, 2005; Heckscher and Adler, 2006; Pettigrew and Fenton, 2000; Tengblad, 2006). Using Heckscher and Applegate's (1994) definition new forms are emerging, but theirs is a very broad definition (see also Heckscher, 1994). Part of the problem with the debate lies in what Barley and Kunda (2001, 2004) have termed 'conceptual inversion', or the tendency for theoretical models in management and organization studies to be formed in direct opposition to traditional modes of organizing, possibly for reasons of heightened academic profile. A related problem is that for some writers (see Donaldson, 1996; McSweeney, 2006; Pettigrew and Fenton, 2000; Pfeffer, 1997) the 'new forms' thesis is yet another fleeting or superficial notion within management and organization studies, one with questionable intellectual depth and reflective, above all, of the 'fads and fashions' tendency (see Collins, 2000). It can be argued therefore that while there are certainly changes in the organizational architecture, hierarchy and bureaucracy undoubtedly remain. Thus, to characterize contemporary organizations as 'post-bureaucratic' may be premature (Clegg and Courpasson, 2004; Du Gay, 2005; Farrell and Morris, 2003; Hales, 1999a, 1999b, 2005; Harris and Höpfl, 2006; Harris et al., 2011; Josserand et al., 2006; Reed and Ezzamel, 2008; Tengblad, 2006).

Finally, of central importance for the present study is the broader theoretical issue of whether the impact of globalization is leading to business system (and thus managerial and organizational) convergence or divergence (Djelic and Quack, 2003; Guillén, 2001; McCann et al., 2010; Tempel and Walgenbach, 2007). The evidence presented in this paper suggests that, although there are some obvious continuities in terms of different national institutional structures (such as loyalty and long-term employment in Japan), restructuring pressures and organizational change measures have been intense and profound in each of the three nations studied, with most driven by a desire to tighten cost control. While it is possibly taking things too far to suggest that this represents a radical shift towards the 'end of careers' in a 'risk society' (Beck, 1992), these changes are nonetheless destabilizing and troubling for middle managers across the world. Whilst managerial careers are not perhaps as insecure as they are often portrayed to be (see Fevre, 2007; Genda, 2005), we argue that managers' feelings of anxiety, insecurity, and low morale are real and understandable given widespread organizational change, the downgrading of career prospects, and the erosion of 
societal and organizational norms about career security and 'jobs for life' under an era of investor capitalism.

\section{Changes to Careers under Investor Capitalism}

Much as the new organizational forms literature is prone to Barley and Kunda's 'conceptual inversion', the same could be said of the managerial careers literature, with the latter, as noted, purportedly undergoing a radical transformation from the traditional 'ladder', located in established internal labour markets in large bureaucratic organizations (Jacoby, 1985) to a new 'boundaryless' form enacted across global corporations (Auer and Cazes, 2000; Carnoy, 2000; Castells, 2000; Cortini et al., 201 1; Handy, 1995; Lazarova and Taylor, 2009; Roper et al., 2011). Indeed the 'new careers' thesis - with its emphasis on reduced career prospects - is premised upon the 'new organization form', in that the latter is characterized by flat structures, delayering, downsizing, and divestment of non-core business activities.

Renewed academic interest in managerial careers was witnessed in the 1990s, with the volume by Arthur and Rousseau (1996) in particular stimulating widespread discussion of concepts such as the 'portfolio', 'free agent', 'protean', 'post-corporate', 'kaleidoscopic', and 'capitalist' career (see also Mainero and Sullivan, 2006; Peiperl and Baruch, 1997). In being increasingly 'boundaryless' (Dany et al., 2003; Eby et al., 2003), these new career arrangements were in turn purported to be less secure, predictable, and organizationally-dependent. Employees would now have 'self-managed' careers - ones which were developed across a range of employing organizations (Miles and Snow, 1996; Weick, 1996). Company and occupational pension schemes would become increasingly 'portable', shifting from the more generous 'defined benefit' to the less generous 'defined contribution’ plans across many nations, including Japan (see Monk, 2009).

Indeed it has been argued that the 'traditional' literature on managerial careers is not aligned well with research into major contemporary workforce transitions (Hall et al., 2002; Ibarra, 2003; Ibarra and Deshpande, 2007). Globalization is said to have led to structural changes which have fundamentally altered the quality and stability of jobs in industrialized countries (Beck, 1992, 1999; Beck and Beck-Gernsheim, 2001; Burtless, 1990; Giddens, 1990, 1994, 2000; Mythen, 2005). As part of this shift to a 'risk' society, traditionally stable and secure 'occupations' have gradually been eroded and replaced by short term and unstable 'jobs' (Gangl, 2004; Kalleberg, 1993; 2003; Kalleberg et al., 2000; Morris and Western, 1999). It is argued that this applies to all grades of employees, including the 'core' workforce, or those formerly protected in established internal labour markets in large bureaucratic organizations. While many critics of this view have argued that this risk society picture is exaggerated - based on popular but unrealistic 'nightmare scenarios' by prominent social theorists such as Anthony Giddens, Ulrich Beck, and Richard Sennett (Doogan, 2001; Fevre, 2007; Webb, 2004) - there are surely grounds for employees to report increases in work- and career-related anxiety and insecurity.

There has, however, been considerable criticism of the 'new careers' concept, much as there has for the new organizational form. Critics have pointed to a lack of empirical data to support the key concept (Gunz et al., 2000), that substantive evidence is limited to 
specific industries (Jones, 1996), and that there is significant variation across industries (Tempest et al., 2004). Indeed some empirical studies, albeit small in number, point to the persistence and resilience of traditional careers (Currie et al., 2006; King, 2003; Zaleska and de Menezes, 2007).

Furthermore, the 'new careers' thesis also appears to lack firm support from the macro secondary data. Despite much management writing pointing to increased job insecurity, in the 1990s long-term tenure rates and levels of job attachment appeared to remain relatively stable in both the USA and UK (Cappelli, 1999; Doogan, 2001, 2005; Fevre, 2007; Jacoby, 1999). In the USA, for example, research by Jacoby (1999) into whether career jobs were 'heading for extinction' suggested that some 35 per cent of the labour force were in post for 10 years plus. His more recent study (Jacoby, 2005) however found, on the one hand, wide variation in levels of career disruption among US firms from 'limited' to 'extreme' - and, on the other, remarkably stable career experiences among Japanese firms. Other evidence suggests that social class remains a key structural factor in career prospects and job tenure (Blossfeld et al., 2006; DiPrete and Nonnemaker, 1997; DiPrete et al., 1997, 2001; Fine, 1998; Gallie and Paugam, 2000; Goldthorpe, 2002; Kerckhoff, 1995; Royal and Althauser, 2003). Job tenure in Japan, at least for core white-collar employees, has remained extremely stable over the last twenty years (Genda, 2005; Matanle, 2003). Meanwhile in Australia, Littler and Innes (2004) found managers 'displaced' by delayering were often redeployed in the same organizations.

This 'insecurity paradox' (Bound and Johnson, 1992; Breen, 1997; DiPrete and McManus, 2000; Fevre, 2007; Turnbull and Wass, 2000) has been explained by a growth in merger and acquisition activity and public sector marketization during recent decades (Farber, 1997; Schmidt, 2000). Moreover, any growth in shorter-term careers may well be a product of increased female participation in the workforce, as women have a history of discontinuous careers (Dany et al., 2003). Indeed it has been argued that the 'new career' may ostensibly be a US-centred phenomenon, although there is evidence of changing career paths in other developed economies (Dany et al., 2003; Guest and Mackenzie Davey, 1996; Lincoln and Nakata, 1997; Van Maanen, 2006). Given such uncertainty, authors such as Barley and Kunda (2004), Mayrhofer et al. (2007), Tams and Arthur (2007), and Thomas and Inkson (2007), for example, have called for career changes to be placed within national and global socio-economic contexts.

The management and organizational literature also points to the existence of conceptual contradictions in the way that careers are prescribed and projected. Such contradictions often reflect the differing orientations of 'managerialist' writers on the one hand and the advocates of a 'critical management studies' on the other (Fournier and Grey, 2000). Advocates of critical management, for example, point to the logical contradictions inherent in the views of mainstream 'prescriptive' writings, where employees are exalted at once to be motivated and committed to their employing organizations whilst managing their careers against a backcloth of increased job insecurity and ever greater task demands (Boudreau and Ramstad, 2007; Granrose and Baccili, 2006; O'Reilly and Pfeffer, 2000; Pfeffer, 1998, 2007). Indeed, in support of the critical perspective, some empirical studies have pointed to reduced levels of organizational commitment and employee motivation in modern corporations (Craig and Hall, 2005; McCann et al., 2010; Sparrow, 1996; Sturges and Guest, 2001; Sturges et al., 2000). While not every 
professional is having his or her career directly threatened, the cumulative effects of widespread and repeated discussions of workplace restructuring and job loss - exemplified in the common phrase 'there are no jobs for life any more' - have understandably induced feelings of anxiety for those hoping and planning to enjoy long careers (Genda, 2005; Heery and Salmon, 2000).

Further, while there would appear to be changes in career patterns, at least as suggested by qualitative studies - including fewer occupational levels, greater job insecurity, a widening senior-middle management divide, increased performance-related pay, and a need for broader skills and less functional specialism (Osterman, 1996, 2009) - there remains the issue of whether such change is genuinely 'transformational' (Porras and Silvers, 1991). If important remnants of the old organizational form remain, as elements of the literature suggest, the likelihood is that many employees will still depend on large bureaucratic organizations for their career development (Currie et al., 2006; Nicholson, 1995; Peiperl et al., 2000). Thus, given the continuing uncertainty over the degree of transformation that has taken place in recent decades, it would appear that further empirical studies are required.

If such questions are largely empirical, there are also broader conceptual concerns that continue to confront organizational and career researchers. Gunz et al. (2000), for example, argue that all careers are inevitably 'bounded', and in diverse ways (see also Barley and Kunda, 2004; Barley and Tolbert, 1997; Zabusky and Barley, 1996). Also, as King et al. (2005) note, 'traditional' and 'new' or 'boundaryless' careers are essentially ideal types, for neither adequately captures the complex interactions between individual agency and structural constraints that circumscribe contemporary organizational experience (see also Barley and Kunda, 2001; Pringle and Mallon, 2003). Similarly, both King et al. (2005) and Inkson (2006) suggest that the notion of 'boundary crossing', rather than boundaryless, may more accurately characterize the modern work career. And, as Duberley et al. (2006) note, in everyday reality, it is often non-work factors that are at the heart of career choice and experience, including the impact of family and personal expectations (see also Eaton and Bailyn, 2000).

Finally, in reviewing the literature on management careers, we must highlight a contribution that has particular relevance for our study. This is the work of Adamson et al. (1998), who note three developments in the philosophy of organizational careers that serve to summarize much of what we have discussed: first, that the employeremployee relationship is no longer perceived to be a long term one; second, that career progress is increasingly lateral, with employees gaining experience across functions and organizations as much as they gain vertical seniority; and third, that individuals and organizations are struggling to understand the likely trajectory of contemporary careers. Central to many of the debates on organizational forms and managerial futures discussed above, these issues frame our enquiry and we address them focally in the results sections below.

Prior sections, then, have provided a detailed review of the literature on changes to organizational forms and careers. The paper will now explore two related issues that arise from the review for our understanding of careers in large corporations. First, what kinds of change have large firms undertaken in recent years? And second, in what ways have these changes affected the job security and career progression of middle managers? 
Instead of claiming to provide absolute or definitive answers to these questions, we use them instead to guide a generic qualitative exploration in which the complex, ambiguous, and sometimes contradictory interpretations of human actors involved in organizational transformation are presented and discussed. Although much of the 'mainstream' literature on management, organization, and careers takes a schematic, formalized approach (Fournier and Grey, 2000), following Barley and Kunda's (2001) call to 'bring work back in' we focus our attention instead on the subjective and inter-personal elements of managerial careers, here considering management itself as a form of work (see McCann et al., 2008, p. 365). Before we can begin to explore our data, however, we must briefly explain the research project and the methodology it adopted.

\section{RESEARGH AND METHODOLOGY}

The research on which this article is based derives from an ongoing international comparative study of 'Management and New Organizational Forms'. The main aim of the research has been to assess the nature of changing organizational forms and managerial careers in mature economies during the first decade of the twenty-first century. Specifically the research has documented the changing experiences of managers in mainly large private and public sector organizations in Japan, the UK, and USA in order to assess the degree of interdependence between managerial careers and organizational reforms under a hypothesized era of investor capitalism. The study was sponsored initially by research council funding in the United Kingdom, with this phase of investigation taking place from 2002 to 2005. Subsequently, from 2006 to 2010 the research was sponsored under recurrent rounds of internal funding from the universities of Cardiff and Manchester. More recently, from 2010, a further external research award has allowed the study to be extended to healthcare sectors in the UK.

The present paper is concerned with evidence from the first two phases of research, 2002-10. During these phases 259 informants were consulted. These consultations ranged from, on the one hand, formal interviews with executives, managers, and supervisors in 26 sample corporations and public organizations to, on the other, a large series of informal interviews, discussions, and communications with: managers from our case organizations who were consulted outside of the workplace; former managers of our case organizations; other professionals with experience relevant to the study (e.g. trade union officials, human resource managers from other sectors); and for each country, a number of academic researchers and analysts working in the field. The research presented here is based primarily on formal interviews conducted in the 26 focal organizations. The majority of these organizations received at least two visits during the recurrent periods of fieldwork undertaken in each country. In all, 142 formal interviews were conducted, with the distribution being: Japan, $\mathrm{n}=37$; UK, $\mathrm{n}=62$; USA, $\mathrm{n}=43$. In addition, relevant documentary evidence and economic data were collected for each organization. The researchers also kept a record of personal observations and case notes on issues relating to organizational change during the regular field investigations in each country.

The aim of the methodology has been to assemble series of company case studies based on interviews with managers in each organization (see Eisenhardt, 1989). As noted, for each organization we have interviewed on the one hand senior and human 
resource managers, and on the other a number of middle managers. In respect of the former, the objective was to gather data on the introduction of new organizational forms and any consequent changes in management, HR, and career practices. We chose to interview senior HR managers in particular because they appeared well placed to provide overviews of organizational changes and the impact these may have had on employee careers. For the latter, we were interested in the impact of organizational changes on the working lives of middle managers, notably on their career expectations and employment experiences. The majority of our senior, HR, and middle manager interviews were conducted on the premises of the various organizations. As noted, however, the process of data collection has also seen former managers of our organizations interviewed as well as in-service managers being consulted outside of the workplace. It was felt that by conducting some of our interviews outside of the walls of a host corporation, this may serve to glean information of a more informal, personal, and critically-oriented nature.

The process of interviewing has generally been based on two of the authors meeting with an interviewee (or interviewees) and recording the meeting on a tape or digital recorder. Such recordings were transcribed subsequently by an external agency. The interview process has seen two main interview schedules designed and deployed. The first, for senior and HR managers, is directed at four issues: company and management information, forms of organizational restructuring, consequences of restructuring for managerial work, and the future work of middle managers; the third and fourth are those mainly relevant to understanding managerial careers. The second schedule, primarily for middle managers, covers six main issues: company and management information, organizational change, job security, career development, changes to work roles, and demographic information; issues two to five are those most relevant to understanding managerial careers. For each schedule, a range of open, closed, and prompt questions were directed at eliciting information under the various themes (Flick, 2006).

The organizations researched are intended to represent a cross-section of industrial, commercial, and public sectors in the USA, UK, and Japan. The objective is that such a design will serve to offset, partially, the criticisms of some of the new organizational forms literature, repeated above, that it researches very narrow, limited, and possibly untypical segments of the economy. Thus the organizations researched in our study reflect private and public sectors, manufacturing and service operations, and modern (e.g. telecommunications, semiconductors) and mature (e.g. automotive, steel) products (see Table I: information derived from research interviews). As far as possible, the organizations were matched across sectors - e.g. financial services, electronics, city administration, public utilities - although the goal of total sector matching could not be fully realized due to some target organizations denying access for research.

Finally, the process of analysis has been that of traditional ethnographic interpretation in industry (Turner, 1972; Van Maanen, 2011; Watson, 1994, 2011). Rather than deploy a qualitative software package (such as Nvivo or Ethnograph) for the coding and classification of data, the research team has generated its own grounded criteria relevant to the project from personal analysis of the recorded data. We argue that this method is more closely aligned with the interpretivist philosophical assumptions (ontological and epistemological) of ethnographic organizational enquiry (Burrell and Morgan, 1979). 
Table I. Sample organizations: activities and headcount at start of research (c.2003-05)

\begin{tabular}{|c|c|c|}
\hline Acronym & Industrial/service activity & $\begin{array}{l}\text { Headcount } \\
\text { (approx.) }\end{array}$ \\
\hline \multicolumn{3}{|l|}{ Japan } \\
\hline JAuto & Automotive & 38,000 \\
\hline JAutoComps & Automotive components & 6,300 \\
\hline JEIComps & Semiconductors, electronic products & 3,200 \\
\hline JEIectronics & $\begin{array}{l}\text { Semiconductors, telecommunications, } \\
\text { ICT }\end{array}$ & 43,500 \\
\hline JFinServices & Merchant banking (branch office) & 300 \\
\hline JLocalGovt & Local authority & 10,500 \\
\hline JRobotics & Industrial robots, engineering & 9,000 \\
\hline JSteel & Steel, related products & 45,000 \\
\hline JUniversity & University & 23,000 \\
\hline \multicolumn{3}{|l|}{ UK } \\
\hline UKAuto & Automotive & 17,000 \\
\hline UKDrinks & Drinks conglomerate & 39,000 \\
\hline UKFinServices & Financial services, insurance & 5,100 \\
\hline UKHospital & University hospital & 3,500 \\
\hline UKLocalGovt & Local government & 16,500 \\
\hline UKSteel & Steel, related products & 25,000 \\
\hline UKUtility & Water, gas, electricity & 15,700 \\
\hline \multicolumn{3}{|l|}{ USA } \\
\hline AAuto & Automotive & 300,000 \\
\hline AEIectronics & Telecommunications, semiconductors & 85,000 \\
\hline AHBank & Financial services & 2,200 \\
\hline AHospital & University hospital & 6,000 \\
\hline AHR & HR outplacement (head office) & 1,000 \\
\hline ALBank & Financial services & 6,500 \\
\hline ALocalGovt & Local authority & 12,000 \\
\hline ARetail & Retailing & 20,000 \\
\hline ASteel & Steel, related products & 10,600 \\
\hline AUtility & Electricity, gas (regional operation) & 6,000 \\
\hline
\end{tabular}

\section{MANAGERIAL GAREERS: ORGANIZATIONAL AND PERSONAL PERSPEGTIVES}

As noted, this section will report primarily on the changing nature of managerial experience in terms of job security and career progression. In so doing evidence is presented from the perspectives of both the organization and the individual. The organizational perspective is expressed mainly through the views of senior and HR managers; the individual or personal perspective through the perceptions of middle managers. In many respects however these views and perspectives interrelate and overlap.

Our data point initially to changing boundaries of the sample firms and public organizations in the three countries studied. In Japan, keiretsus were seen to be moving to looser forms with fewer, larger, preferred suppliers and, in the public sector, increased 
Table II. Reported restructuring in sample organizations (decade preceding start of research: c.1993-2005)

\begin{tabular}{|c|c|c|}
\hline Acronym & Reported downsizing & Reported delayering \\
\hline \multicolumn{3}{|l|}{ Japan } \\
\hline JAuto & c. 9000 staff & 3 layers removed \\
\hline JAutoComps & c.1000 staff & 2 layers removed \\
\hline JEIComps & c.800 staff & 2 layers removed \\
\hline JEIectronics & c. 12000 staff & 1 layer removed \\
\hline JFinServices & 'None' & 0 layers removed \\
\hline JLocalGovt & c.4000 staff & 0 layers removed \\
\hline JRobotics & c.4000 staff & 4 layers removed \\
\hline JSteel & 'About 33\%' & 2 layers removed \\
\hline JUniversity & 'Small amount' & 0 layers removed \\
\hline \multicolumn{3}{|l|}{ UK } \\
\hline UKAuto & c.8000 staff & 3 layers removed \\
\hline UKDrinks & c.30000 staff & 4 layers removed \\
\hline UKFinServices & c. 1000 & 5 layers removed \\
\hline UKHospital & 'No data' & 3 layers removed \\
\hline UKLocalGovt & c.1800 staff & 4 layers removed \\
\hline UKSteel & c.9000 staff & 2 layers removed \\
\hline UKUtility & 'Extensive redundancies' & 0 layers removed \\
\hline \multicolumn{3}{|l|}{ USA } \\
\hline AAuto & 'About 30\%' & 1 layer removed \\
\hline AEIectronics & c.70000 staff & 7 layers removed \\
\hline AHBank & c.500 staff & 1 layer removed \\
\hline AHospital & 'Yes' (unspecified) & 'Yes' (unspecified) \\
\hline AHR & 'Yes' (unspecified) & 2 layers removed \\
\hline ALBank & 'Yes' (unspecified) & 4 layers removed \\
\hline ALocalGovt & 'Limited amount' & 0 layers removed \\
\hline ARetail & 'None' & 0 layers removed \\
\hline ASteel & 'None' & 0 layers removed \\
\hline AUtility & c. 1600 staff & 5 layers removed \\
\hline
\end{tabular}

outsourcing. In the USA, organizational boundaries had also shifted, with extensive outsourcing and divestment of 'non-core' activities in automotive, electronics, financial services, utilities, and health. And in the UK, the majority of organizations reported shifting boundaries, this being most pronounced in larger, older, firms which had often moved away from vertically integrated operations, commonly through divestment or outsourcing. This pattern was not confined to the private sector, however, with public sector organizations (local authorities, for example) also subject to compulsory marketization of services and consequent contracting out.

While organizational boundaries were evidently shifting, to what extent were new structures emerging, particularly through delayering and downsizing? Table II summarizes the structural changes reported for each sample organization during the initial round of interviews. This information reflects responses to questions concerning forms of change within the organization during the previous decade. As the majority of initial interviews were completed 2003-05, the 'decade of change' accounted for in each 
organization reflects approximately the period 1993 to 2005 (although many managers talked generally about changes from the early 1990s onwards).

Downsizing was evident not only within firms in the US and UK samples but also, perhaps counter-intuitively, within some of our Japanese organizations. Downsizing in the USA and UK had typically started much earlier than in Japan, notably in the early 1990s for managerial reductions. In Japan downsizing was widely reported from roughly the mid-1990s onwards, with headcount cuts of the order of 20-30 per cent (see Ahmadjian and Robinson, 2001). In some cases this was due to the relocation of production operations overseas, frequently to China. A feature of this downsizing data was that compulsory redundancies were rare in Japan, with companies relying instead on dramatic hiring reductions, early retirement, and shukkō transfers of older managers to affiliates (often on inferior terms and conditions). During the decade accounted for, all but two of the US sample had downsized. In the case of one of the largest organizations the headcount reduction approached 50 per cent, with both managerial and blue-collar jobs being lost. US sample organizations relied most heavily on compulsory redundancies, with some firms adopting a system of 'forced ranking', known colloquially as 'rank and yank', where the lowest 10 per cent performing managers were made redundant every year, a methodology made famous by General Electric under Jack Welch and also used at Enron. Interviews suggested that this approach was being considered by several firms in the sample, and notably so in one corporation where the Senior HR executive reported that he been recruited primarily because of his experience with the General Electric system. The UK sample was ostensibly similar to the US sample in reflecting widespread managerial downsizing, although compulsory redundancies were rarer.

If downsizing does not necessarily imply organizational restructuring, delayering certainly does. In Japan, the majority of sample firms had reduced their number of managerial layers. This obviously has implications for careers, promotion, and motivation of middle managers. These factors have particular salience in Japan where career development and promotion have largely been synonymous with seniority. In Japan, delayering was prominent in manufacturing firms, with, for example, 2 of 5 layers being taken out in one and 4 of 7 in another. This was apparently motivated by a perceived need to speed-up decision making and reduce costs, and resulted in work intensification, broader task roles, increased spans of control, and far fewer promotion opportunities.

These developments had predictably made a major impact on the nature of managerial work and roles, particularly for middle managers. In the Japanese manufacturing organizations, for example, traditional supervision and management duties were frequently combined with a new expert role and project management tasks, the result being work intensification. For the middle managers interviewed, a 12-hour day was apparently normal and 15-16 hours far from unusual. All of our Japanese HR managers reported problems with motivating middle- and junior-level managers. In some organizations such concerns were linked to reduced peer group solidarity and more individualistic behaviour associated with changes in pay systems.

In the USA, our HR manager respondents also noted work intensification due to broader spans of control and extended task domains, with such factors frequently being linked to downsizing and delayering. Associated motivational problems were reported by HR managers at five of the organizations researched. Similarly HR managers in the UK 
reported moves to a qualitatively different work environment, with none reporting 'no change'. Respondents reported extended task domains, a consequent increase in stress for middle managers, and associated motivational problems; which tended to reflect a culture of 'normalized intensity' (McCann et al., 2008).

Interviews with US middle managers broadly confirmed the views of our US HR managers, albeit that the former were far more critical of contemporary organizational change. They described repeatedly the onset of longer working hours, extended task domains, and increased responsibilities, although the latter did not always equate to the experience of greater autonomy. Japanese middle managers reported work intensification, greater work complexity, and increased job scope, while UK middle managers tended to describe intensification and a more competitive business environment.

\section{Job Security}

While perceptions of the nature of managerial careers in light of changes to organizational forms often focus on role scope and prospects for advancement, closely related are issues of job security, or at least perceived job security, on the part of managers. Notions of job security and career are, of course, to a degree mutually exclusive in that you may have job security without career progression prospects and conversely career prospects without job security. However, at least in the perceptions of many of our sample managers, they appear to be closely and intimately related, in fact reflecting an increasing 'insecurity culture' in work organizations. Respondents were often long-term employees of the companies studied, and, as will be shown below, were very forthcoming with their opinions on how their careers had changed over time. They frequently referred to the weakening of organizational and social norms about job security and the demise of the long-term career in the modern corporation. The data reported in this section, therefore, focus on two related issues: first, the impact of organizational restructuring upon job security; and second, the resulting perceptions of managers as to their future career prospects (see Arthur et al., 2005).

Organizational restructuring is only one aspect of change. Equally important are consequent changes to human resource management systems. Nowhere is this truer than in Japan, where traditionally there is a close relationship between elements of organizational structure (e.g. established internal labour markets), job tenure (e.g. lifetime employment), and remuneration (e.g. seniority-based pay systems). In brief, the traditional 'lifetime' employment system would seem to remain deeply embedded within Japanese organizations, albeit that it applies to a progressively smaller percentage of the workforce and is for a shorter duration. In this respect, Berggren and Nomura's (1997) notion of 'long-term employment' is now perhaps more apt than lifetime employment. Moreover, in our Japanese companies, there were increasing numbers of mid-career hires, an employment phenomenon previously unusual in that economy. This has significant implications for job security and, more importantly, for the career prospects of in-situ managers, which we return to later.

The issue of careers cannot be separated of course from the broader socio-economic environment. Careers are inevitably bounded by, amongst other things, a manager's 
non-work life circumstances. They are also shaped by national level institutions, either formally or informally. In Japan, for example, many HRM policies and practices reflect informal, but deeply embedded, socially powerful and path-dependent career factors, notably in respect of pay and promotion. Moreover, at the formal level it has traditionally been difficult in Japan to dismiss legally so-called 'regular' or 'typical' workers. While such legislation has indeed been relaxed in Japan, it still remains stronger than in the USA or UK. Similarly, the role and influence of trade unions varies significantly between the nations studied. Thus, at the organizational level, careers are bounded by organizational structures and HR norms; for as previous sections have indicated, changes to structures and norms potentially impact on career patterns.

In each of the three countries studied our HR managers acknowledged that managerial job security had diminished, although it was far more pronounced in the USA and (albeit to a lesser extent), the UK, than in Japan. This was perhaps unsurprising given the number of major headcount reduction exercises in US industry in recent decades and the long-term erasure of New Deal era employment legislation. Evidence of the onset of a job insecurity culture appeared most pronounced in two of the largest, and oldest, US organizations we visited, AAuto and AElectronics, although there was similar evidence of a climate of uncertainty at two of the youngest firms studied, where downsizing had not yet occurred, ASteel and ARetail. The HR Director at AElectronics, for example, described the change from a situation which pertained up until the 1980s, whereby a de-facto 'jobs for life' policy had existed for employees with over ten years' service. However, from the early 1990s the organization had followed others in the sector by installing a 'forced ranking' policy whereby, as noted, the bottom 10 per cent of managers in terms of assessed performance were dismissed each year.

This reduction in job security in US organizations was also reported by the middle managers we consulted. At AAuto, for example, in a discussion related to the effects of 'lean' manufacturing aimed at removing wasteful or unnecessary levels of management, one middle manager reported that:

The middle ground has been left in the dock as the lean boat has sailed away.

Similarly, a middle manager at ASteel reflected:

Well I would say that it's changed because ... now everybody's in a flux, everybody's not sure of anything, and so I think that helps the concept that really job security is in you as an individual.

In Japan, the issue of job security was perhaps more subtle and nuanced than in the USA. This is largely a reflection of the fact that compulsory redundancies, at least of permanent employees, had not yet taken place. Nevertheless, HR managers at five of our Japanese organizations expressed the view that levels of job insecurity had increased 'significantly'. As the HR manager at JElectronics noted, the issue of increased job insecurity has been circulating in society for some time. Traditional norms are widely understood to be eroding: 
That's about job insecurity, or a sense of insecurity, yes that might be true, but it's not just about our company, but you know all of the companies in Japan too . . . So in a sense people are already aware that their jobs are not guaranteed until they reach retirement age.

A relatively young manager at JFinServices noted that:

Actually lifetime employment is good; because you are ensured that you get paid ... but big companies are changing away from lifetime [employment].

Voluntary early retirement was encouraged in the majority of our Japanese organizations, with several part-severing employment contracts when managers reached middle age. At JAutoComps, for example, middle managers were expected to 'retire' at age 53, at which time they may be transferred elsewhere in the organization, or to an affiliate, on considerably inferior employment terms and conditions. Moreover, all of our Japanese organizations had significantly reduced the number of workers hired and several had changed from a policy of recruiting at age 18 or 22 to hiring 'mid-career', thereby reducing the overall numbers of people with job security. At JAuto for example, 50 per cent of new hires were reported to be mid-career.

In the UK, despite the fact that compulsory redundancies had not been as prevalent as in our US organizations, an awareness of increased job insecurity pervaded the sample. The majority of HR managers we interviewed felt that levels of job security had diminished 'significantly'. UKAuto's HR manager, reflecting on the relation between manufacturing technology investment and the future of his site, noted that:

Does this secure the plant? Sort of, but with the older technologies it would have, but with the new flexible machining centres, they are relative easy to move.

Similarly, the HR manager at UKSteel noted that:

And you look at the graduate retention figures, for example, and you ask: well, why have people left? And it is something to do with kind of stabilizing, security, company image, particularly over the last 2 or 3 , or 4 or 5 years, because of what we have been through.

With the exception, perhaps, of UKHospital, these feelings of insecurity were shared by middle managers across all of the UK organizations we visited. At UKAuto, for example, a manager responded to a question on job security by answering:

I just assume there isn't any security anymore and even at this plant we are only as good as our next engine... it's just literally get on with it, yes, not let it worry you ... you can only do what you can do and do it to the best of your ability.

At UKUtility, a manager noted that his job was: 
As secure as running a new business, I have no doubt that I won't be here in twelve months if I don't secure new business . . . I have no choice.

A second manager at UKUtility added:

I don't believe it's a job for life any more, and so [you have to] take chances and responsibility for your own career and your own life. It's not a job from cradle to grave.

A manager at UKFinServices was perhaps less sanguine when she commented:

So you almost felt like there's someone eyeing my job, and am I going to be back in a selection process and having to fight for my job. And that uncertainty was appalling ... That kind of change, that kind of uncertainty really can be destructive for people.

In sum, significant restructuring has taken place in almost all of the organizations studied, creating numerous challenges and concerns for middle managers. Recurrent changes to structural forms, work roles, and norms about careers have often seemed linked to an anxiety-inducing, morale-sapping environment for middle managers, one in which traditional notions of job security were being eroded. In the next section, we look specifically at the impact of such change on managers' career progression. In doing so we note that disruption to traditional career paths is common in our case studies, even in Japan, a nation with very strong norms about occupational longevity and organizational hierarchy.

\section{Career Progression}

Traditionally managerial career progression in Japan has been closely aligned to the seniority system. For a number of reasons, however, the seniority-based pay system appears under more threat than lifetime employment. First, evidently Japanese companies have long been seeking cost reductions due to economic recession. Second, the seniority system depends on having a certain percentage of managers in various age groups; with hiring-freezes there are now fewer younger, less well paid, managers. Third, there is evidence that to a certain extent the seniority system is being sacrificed to shore-up the lifetime employment system. And fourth, Japanese organizations are increasingly attracted to adopting pay systems that are supposedly more responsive to individual and group performance.

In relation to career progression, our data on changes in the Japanese seniority system can be summarized as follows. First, promotion prospects which were virtually guaranteed under the traditional system are no longer certain. At JSteel, for example, informants suggested that formerly c.80-90 per cent of managers would reach the top two payment grades and c.45 per cent be promoted to Bucho-level. Under the new system, however, the approximate figures were 40 per cent and 10 per cent, respectively. Second, the time taken to achieve promotion, traditionally long, had been reduced across firms and public organizations. At JLocalGovt, for example, informants suggested the age of 
first promotion had dropped 'from late 30s to early 30s', although seniority stilled play 'a major role' in such processes. And third, there was evidence of organizations becoming increasing disposed to individual and group-based pay systems. Under the Satei system (see Endo, 1998), for example, a performance element in pay has long been part of remuneration in Japanese companies, but this often resulted in corporate-wide bonuses. Our interviews suggested that elements of individual pay and remuneration differentiation were increasing in all the private sector Japanese organizations studied, albeit within the same grades. Although changes in HRM practices were less marked in Japan than in the USA and UK, significant adjustments were apparent, notably at two of the largest corporations, in electronics and automotives.

Developments such as these suggest less formulaic and pedestrian progression for the managers in our sample organizations. Downsizing and delayering create situations where there are far fewer opportunities for managers to progress. Moreover, our data suggest an increasing managerial bifurcation between a small cadre of 'high fliers' destined for fast-track elevation to senior positions - and a rump of long-term middle managers, continually moving sideways to increase their 'experience'. As a consequence of delayering, the former have greater opportunity to progress while prospects for the latter are much less certain. Evidence for this was found in corporations from each of the three countries studied, but notably so in global multinationals. While this may not be a deliberate or conscious strategy it would appear to be at least an unintended, or unforeseen, consequence of the emergence of 'new forms', a problem which organizations are currently attempting to grapple with.

Our evidence suggests, therefore, that managerial career progression is becoming more difficult across the majority of sample organizations in Japan, the USA, and UK. Overall our organizations are placing a greater emphasis on lateral rather than vertical mobility, although several had made it easier for a small percentage of managers to be promoted far sooner than traditionally would be the case, and even to jump grades. However, HR managers across our national samples acknowledged the limitations of such policies. Even senior managers in Japan often noted the problem of motivating managers in a scenario of work intensification, long hours, and reduced promotion opportunities.

We have of course also noted the policy, adopted by many of our sample organizations, of increasingly aligning pay with individual and small group performance, thus deploying incentive systems other than step-wise promotion. Although in Japan pay is still generally aligned with job grades or titles, the HR manager at JAutoComps, for example, noted how:

When the company was growing, rapidly, [it] provided most of the managers with promotion, but when the growth stopped [it] had to transform the system. This is mature [the traditional system is now out of kilter]; we can't sustain it anymore, so this is the new [performance-related] system.

In addition, we noted the growing tendency in many of our Japanese corporations for freeing-up management positions through various schemes related to early retirement. 
Promotion prospects also appeared reduced in our US organizations, with lateral career development being emphasized along with individualized pay. As in the Japanese sample, the longer term motivational limitations of such a strategy were evident to US HR managers. Moreover, with delayering, promotion was now a major step in career terms, particularly given the work intensification that would result. As the HR manager at AUtility noted:

One of the fallouts that I have seen is that many times people take a step-up without having developed some of the required capabilities . . . I've seen many instances in this company where . . . people might get promoted into a higher senior position without being through some of the steps. And then they are not really equipped or they don't really have those capabilities.

Our UK organizations similarly had increasingly deployed a strategy of lateral career development as an alternative to regular step-wise progression, but as in the USA and Japan, motivational issues were identified. Several UK HR managers noted problems arising from managers being asked to make large vertical career moves as a direct result of delayering. The HR manager at UKAuto, for example, noted how:

Not all PTMs [Production Team Managers] can get promoted in this lean structure, that's the crux of it. And the fortunate ones have got there very quickly. So this delayering has taken out what I call the development grades. There are now huge levels of risk taken with people. But the acid test is - it doesn't allow development.

While this response appears to suggest disillusionment with a lack of career opportunities in downsized and delayered organizations, some respondents, however, were more positive when describing the increased competition for higher-grade posts under such arrangements. A young manager at UKDrinks, for example, commented:

Me personally? It's quite interesting because the number of promotional opportunities within this part of the business has probably declined by 50 per cent since I started. Does that problem faze me? No . . I wouldn't be sitting in this position if I hadn't got a step up the rung.

However, for the middle managers we interviewed, such positive views were clearly in the minority. The majority of our informants were extremely negative about their career prospects, with manager after manager reinforcing this view in Japan, the USA, and UK (Hassard et al., 2009). In Japan, for example, a manager at JAutoComps commented that:

You picked a tough question. That's a big question, because in the past everyone got promoted, so you had something to look forward to. And these days more and more people are left behind, sort of in the bottom level, and the bottom level is becoming big. 
A colleague at JAutoComps added:

Recently society is changing very quickly. In the past you just had to do routine work and got promoted automatically. But today routine work is not enough.

Meanwhile in the USA, a middle manager at AAuto noted that:

In particular my career has stalled. This is because, in my opinion, there are fewer jobs to go into ... It has certainly slowed to the point where I have no reason to believe that I will be promoted before I retire ... And if I had one of my sons here I would say 'start looking somewhere else'.

Many UK managers were also pessimistic about their future career prospects. A manager at UKDrinks, for example, noted:

They didn't sit down with me for instance at any stage and say 'OK, this is what you need to develop your career' ... It is a fact that, because of the quality of people in middle management, and because of the delayering, those changes mean that career opportunities for me are going to be very limited. I mean in my own case, I've done the Area Manager's job for several years. There isn't an opportunity for me to stay in that role. I will go back to, well, it won't be a lesser role, but to a less desirable role for myself.

Our research also noted ways in which the careers of many of our sample managers were often circumscribed by non-work life issues and commitments. Several UK managers noted the difficulties of making either lateral or vertical job moves when having significant family commitments, especially young children, to consider. Some indeed suggested that due to the nature of such commitments they did not want career progression. A manager at UKFinServices, for example, reflected:

Until this role was created I was pretty much thinking: 'Where am I going to go next?'. 'My boss works even longer hours than I work'. 'Do I really want his job?'

Similarly, a manager of UKLocalGovt suggested:

Well I don't actually want to get the next tier up, because obviously it's even more stressful than what I've currently got. I don't want to do that.

Finally, a middle manager in one of our public organizations offered an explanation for such sentiments when describing the kind of stress that radical restructuring can place not only on career progression but also on enterprise management as a whole:

We are having nightmares as a tier of management has been removed and their responsibilities devolved downwards a tier. Of course, that tier has devolved their old stuff downwards too and concentrated on their new stuff. However, the tier that was 
removed has really only been given a new managerial grade upwards, leaving a gaping hole . . . For my department, it means I currently don't have a manager at all, so one of the seniors is going to manage me at arm's length.

Highlighting the potential stress caused by role intensification and career uncertainty, this manager offered a personal theory of how restructuring in his part of the organization had been extended to irrational extremes:

It's hysterical. In fact it's what I call 'Fuck It Management', where managers are given responsibility and they say 'fuck it, someone else can do that'. Someone else gets it, and says 'fuck it' also, and so on, ad infinitum. I did have a manager, but he was only doing it as a favour, so said 'fuck it', literally, and left last week and went back to his old job. There are no plans to replace him, as we haven't advertised vacancies for two years, and out of 250 staff we have lost 50, the idea being that we can all do more work for the same pay. I've got about 60 hours overtime in since Christmas [as of end March], but can't get paid for it. So if I take it as time off I get further and further behind. The whole thing is crazy.

\section{DISGUSSION AND GONGLUSION}

Our findings indicate that new forms of organizing were widespread across the sample organizations investigated in the three countries studied; at least as defined by the changing nature of internal and external boundaries (e.g. by downsizing and delayering on the one hand and outsourcing and divestment on the other). While we would question the extent to which this represents 'transformational post-bureaucracy' (Heckscher, 1994) or alternatively is indicative of 'neo-bureaucratic' hybrid forms of structure emerging (Farrell and Morris, 2003), it nevertheless has significant implications for managers in our organizations in terms of their work roles, job security and, crucially, career prospects.

Issues of job security were acknowledged both by the 'organizational representatives' (i.e. senior and HR managers) we interviewed as well as those in middle management positions, but far more acutely by the latter. These concerns manifested themselves in different ways: they were impressed upon us most starkly in the responses of US managers, but were also striking in those of many UK and Japanese managers. This is in part reflective of the varying restructuring methods deployed by organizations in the three countries. In US organizations, recurrent rounds of compulsory redundancies had been experienced, whereas in the UK they were somewhat less common, and in Japan rare. Nevertheless, in the UK there were several instances of middle managers having to compete for their existing jobs, while in Japan organizations had 'downsized' by extensive recruitment freezes and early retirement schemes. Indeed, in Japan managers were aware that the normative expectations of lifetime employment could no longer be sustained and that early retirement was increasingly likely.

Given the changes in organizational context, career prospects for managers were almost inevitably diminished. Organizations were mitigating the impact of reduced upward mobility by moving managers laterally; although the extent to which this can be 
deployed over time is questionable. The potentially problematic implications of such practices for manager motivation, employee commitment, and organizational loyalty were recognized by the senior and HR managers we consulted. This is in line with the observations of Adamson et al. (1998) that firms are acutely aware of the tensions that delayering has on careers, motivation, retention, etc., and that to compensate for a lack of promotion prospects, organizations are attempting to deal with this in a variety of ways. However many of the managers consulted expressed the view that these were at best 'stop-gap' measures; ones that would serve only to motivate and retain managers in the short to medium term.

The responses of managers to changes in career development trajectories varied, but can be classified into four broad categories. First, many older managers were resentful of the lack of future career advancement opportunities, particularly in a context where their work regimes had intensified. Second, younger managers were often resigned to such scenarios, being largely accepting of them as part of the employment culture of contemporary capitalism; they accepted having to move locations and even employers frequently if their career aspirations were not met. Third, there was a small group of younger managers who viewed delayering as an opportunity to progress more quickly than might have previously been the case. And fourth, there was a group, again small, who were not actively seeking further progression; for they perceived that this would serve only to increase their personal levels of stress and/or further worsen their work-life (im)balance.

Should the career paths described in our research, therefore, be described as traditional, bounded, boundary-crossing, or boundaryless? Certainly, within our organizations, 'traditional' careers have been modified in that on the one hand there are far fewer vertical or 'advancement' opportunities and on the other, far more lateral or 'developmental' ones. We also witnessed many managers who possessed long tenure yet who no longer took for granted or even anticipated a guaranteed career in-company. However, there was little evidence of managers proactively embarking on 'boundary-spanning' or 'boundaryless' progression in the way that much of the careers literature suggests. Indeed, the careers of many of our sample managers were 'bounded' by a number of factors, including location, spouse's occupation, family obligations, work-life balance, etc. This was particularly, but not exclusively, true of female managers in the USA and UK; we only interviewed one female manager in Japan, who was single and worked in the public sector.

While mindful of the wide array of forms careers may take in different economic sectors, organizational types, geographic regions, or even 'varieties of capitalism', we can nevertheless identify a set of broad propositions that emerge from our data. This study has deliberately explored large organizations that had histories of bureaucratic structures and traditional career systems. As such, our propositions may not hold in other spheres, such for as small and medium-sized enterprises, or younger, more 'postmodern' organizations. However, we would expect them to have fairly broad relevance for large organizations in mature economies.

Fundamentally, we argue that during the first decade of the twenty-first century, changes to contemporary managerial careers have been driven by substantial and significant organizational change, which has had three major impacts. 
First, changes to the structure and composition of managerial roles in large organizations have typically led to career stagnation for middle managers. Downsizing and delayering have resulted in the number of managerial positions and administrative layers being reduced significantly; as a result there are far fewer posts for middle managers to be promoted into. Given also that the relative distance between rungs on the managerial ladder has increased, this has promoted policies of lateral career development. Overall, these related factors have served to limit career prospects and heighten promotion competition.

Second, in attempting to become progressively 'leaner' and 'flatter', large corporations have also reduced the traditional career entitlements of middle managers, a trend that reflects a culture of job insecurity. Although this trend can be exaggerated, it is reflected in the artefacts of contemporary employment policy within large organizations, viz. geographical relocation, 'rank and yank', position reapplication, voluntary redundancy, early retirement, reduced pension rights, and the general rollback of the 'psychological contract'. Such changes have led to erosion of the loyalty shown by organizations to managers and by managers to organizations. Crucially, such changes promote awareness that a 'job for life' is a thing of the past.

And third, the above changes to managerial careers and organizational forms are increasingly international phenomena. While at the national or societal level these changes are mediated by various path-dependent institutional norms - as described by varieties of capitalism scholars - large firms in economies as different as Japan, the UK, and USA have faced substantial increases in levels of competition, thus creating a powerful imperative for deploying cost-reduction strategies. At the same time, large organizations across the globe have been influenced by a number of generic consulting philosophies directed at facilitating radical organizational change.

Further empirical research across other nations and sectors would, of course, be required in order to test further the validity of these propositions. Indeed it can be argued that managerial careers are more complex and messy than both the 'traditional' or 'boundaryless' ideal-types suggest, and this has probably been the case for some while in the USA and UK. Nevertheless we conclude that a trajectory is discernable, as expressed in the above propositions. Even those managers with extremely long service within a single organization perceive contemporary careers as being increasingly unstable. Expressions of dismay, anxiety, and insecurity on the part of middle managers are perfectly understandable responses to this trajectory, and should not be dismissed as somehow irrational or unexplainable, as some critics of the risk society thesis (notably Fevre, 2007) tend to do. In several respects, therefore, our research supports the view of Adamson et al. (1998) that, in the USA and UK in particular, the employer-employee relationship is no longer perceived to be a long term one, notably on the part of employees. Increasingly organizations and their managers are struggling to understand and cope with the anxiety generated by contemporary career trajectories and the deep contradictions and tensions of organizational change.

This raises finally the question of to what extent do changes to contemporary managerial careers need to be placed in global and national employment contexts (see Barley and Kunda, 2004; Mayrhofer et al., 2007; Tams and Arthur, 2007; Thomas and Inkson, 2007)? Or put another way, were there notable differences between the USA, UK, and 
Japan? In many ways the similarities between forms of organizational restructuring and their impacts are striking. Certainly, managerial career advancement prospects are increasingly circumscribed and limited in the three countries studied. However, differences did emerge. Managers in the USA, and to a lesser extent in the UK, were aware of an increasing lack of job security, with, in the USA at least, there being good reason, given the prevalence for compulsory redundancies associated with downsizing. Although evidence of an increasing sense of insecurity was witnessed in Japan also, this trend was not as acute, for even where managers were pressed into early retirement they would then typically transfer into another job in an affiliate, albeit on inferior terms and conditions. Nevertheless, this break with the normative expectations of a job-for-life was significant for our Japanese managers and clearly articulated. It also appeared to generate some definite feelings of anxiety and dismay among the middle managers interviewed. In the words of Genda (2005, p. 2), a 'vague sense of anxiety with no clear basis in fact, is rampant in Japan'.

However, from our findings we would argue, overall, that there is some basis in fact for such feelings. From our three nation study, a heightened sense of anxiety and uncertainty is precisely the sort of psychological phenomenon associated with the growth of the insecurity or risk society thesis, and notably so in the UK and USA. Given the similarity of changes to structures and careers, increased uncertainty and anxiety are perhaps inevitable responses to the challenges of working in large organizations under the heavy demands and risks of the shift from managerial to investor capitalism.

\section{ACKNOWLEDGMENT}

We would lie to thank the Economic and Social Research Council of the UK for funding the initial research phase, entitled 'Management and New Organizational Forms: Middle Management in the UK, USA and Japan' (R000239288).

\section{REFERENGES}

Adamson, S. J., Doherty, N. and Viney, C. (1998). 'The meanings of career revisited: implications for theory and practice'. British Fournal of Management, 9, 251-61.

Ahmadjian, C. L. and Robinson, P. (2001). 'Safety in numbers: downsizing and destitutionalization of permanent employment in Japan'. Administrative Science Quarterly, 46, 622-54.

Alvesson, M. and Thompson, P. (2005). 'Post-bureaucracy?'. In Ackroyd, S., Battt, R., Thompson, P. and Tolbert, P. S. (Eds), The Oxford Handbook of Work and Organization. Oxford: Oxford University Press, 485-507.

Arthur, M. B. (2008). 'Examining contemporary careers: a call for interdisciplinary inquiry'. Human Relations, 61, 163-86.

Arthur, M. B. and Rousseau, D. M. (1996). 'Introduction: the boundaryless career as a new employment principle'. In Arthur, M. D. and Rousseau, D. M. (Eds), The Boundaryless Career: A New Employment Principle for a New Organizational Era. Oxford: Oxford University Press, 3-20.

Arthur, M. B., Inkson, K. and Pringle, J. K. (1999). The New Careers: Individual Action and Economic Change. London: Sage.

Arthur, M. B., Khapova, S. N. and Wilderom, C. P. M. (2005). 'Career success in a boundaryless career world'. Fournal of Organizational Behaviour, 26, 177-202.

Auer, P. and Cazes, S. (2000). 'The resilience of the long term employment relationship: evidence from the industrialized countries'. International Labour Review, 139, 379-408. 
Balogun, J. and Johnson, G. (2004). 'Organizational restructuring and middle manager sensemaking'. Academy of Management Fournal, 47, 523-49.

Barley, S. and Kunda, G. (2001). 'Bringing work back in'. Organisation Science, 12, 76-95.

Barley, S. and Kunda, G. (2004). Gurus Hired Guns and Warm Bodies: Itinerant Experts in a Knoweledge Economy. Princeton, NJ: Princeton University Press.

Barley, S. and Tolbert, P. (1997). 'Institutionalization and structuration: studying the links between action and institution'. Organization Studies, 18, 93-117.

Batt, R. (1996). 'From bureaucracy to enterprise? The changing jobs and careers of managers in telecommunications service'. In Osterman, P. (Ed.), Broken Ladders: Managerial Careers in the New Economy. New York: Oxford University Press, 55-86.

Beck, U. (1992). Risk Society. London: Sage.

Beck, U. (1999). World Risk Society. Cambridge: Polity Press.

Beck, U. and Beck-Gernsheim, G. (2001). Individualization, Institutionalized Individualism and Its Social and Political Consequences. London: Sage.

Berggren, C. and Nomura, M. (1997). The Resilience of Corporate Japan: New Competitive Strategies and Personnel Practices. London: Paul Chapman Publishing.

Blossfeld, H., Mills, M. and Bernardi, F. (Eds) (2006). Globalization, Uncertainty and Men's Employment Careers: A Theoretical Framework. Cheltenham: Edward Elgar.

Boudreau, J. W. and Ramstad, P. M. (2007). Beyond HR: The Science of Human Capital. Boston, MA: Harvard Business School Press.

Bound, J. and Johnson, G. (1992). 'Changes in the structure of wages in the 1980s: an evaluation of alternative explanations'. American Economic Review, 82, 371-92.

Breen, R. (1997). 'Risk, recommodification and stratification'. Sociology, 31, 473-91.

Budros, A. (1999). 'A conceptual framework for analyzing why organizations downsize'. Organizational Science, 10, 69-82.

Burrell, G. and Morgan, G. (1979). Sociological Paradigms and Organisational Analysis. London: Heinemann.

Burtless, C. (1990). 'Introduction and summary'. In Burtless, G. (Ed.), A Future of Lousy Fobs? The Changing Structure of US Wages. Washington, DC: Brookings Institute, 1-27.

Cappelli, P. (1999). 'Career jobs are dead'. California Management Reviewe, 42, 146-67.

Carnoy, M. (2000). Sustaining the New Economy: Work, Family and Community in the Information Age. Cambridge, MA: Harvard University Press.

Castells, M. (2000). 'The rise of the network society'. In Castells, M. (Ed.), The Information Age: Economy, Culture and Society, Vol. 1. Oxford: Blackwell, 1-38.

Child, J. and McGrath, R. G. (2001). 'Organizations unfettered-organization form in an informationintensive economy'. Academy of Management Fournal, 34, 653-82.

Clegg, S. (2011). 'Under reconstruction: modern bureaucracies'. In Clegg, S., Harris, M. and Hofpl, H. (Eds), Managing Modernity: Beyond Bureaucracy? Oxford: Oxford University Press, 275-302.

Clegg, S. and Courpasson, D. (2004). 'Political hybrids: Tocquevillean views on project organizations'. Journal of Management Studies, 41, 525-47.

Cohen, L. and Mallon, M. (1999). 'The transition from organizational employment to portfolio working and perceptions of boundarylessness'. Work, Employment and Society, 13, 329-52.

Collins, D. (2000). Organizational Change: Sociological Perspectives. London: Routledge.

Cortini, M., Tanucci, G. and Morin, E. (Eds) (2011). Boundaryless Careers and Occupational Wellbeing. London: Palgrave.

Craig, E. F. and Hall, D. T. (2005). 'The new organizational career: too important to be left to HR?'. In Burke, R. J. and Cooper, C. L. (Eds), Reinventing HRM: Challenges and New Directions. London: Routledge, $755-74$.

Currie, G., Tempest, S. and Starkey, K. (2006). 'New careers for old? Organizational and individual responses to changing boundaries'. Human Relations, 17, 755-74.

Dany, F., Mallon, M. and Arthur, M. B. (2003). 'The odyssey of career and the opportunity for international comparison'. International Fournal of Human Resource Management, 14, 705-12.

DiPrete, T. A. and McManus, P. A. (2000). 'Institutions, technical change and diverging life chances: earnings mobility in the United States and Germany'. American fournal of Sociology, 102, 343-70.

DiPrete, T. A. and Nonnemaker, L. K. (1997). 'Structural change, labour market turbulence and labour market outcomes'. American Sociological Review, 62, 386-404.

DiPrete, T. A., De Graaf, P. M., Luijkx, L., Tahlin, M. and Blossfeld, H. P. (1997). 'Collectivist versus individualist mobility regimes? Structural change and job mobility in four countries'. American fournal of Sociology, 103, 318-58. 
DiPrete, T. A., Goux, D., Maurin, E. and Tahlin, M. (2001). 'Institutional determinants of employment chances. The structure of unemployment in France and Sweden'. European Sociological Review, 17, 233-54.

Djelic, M. L. and Quack, S. (Eds) (2003). Globalization and Institutions: Redefining the Rules of the Economic Game. London: Edward Elgar.

Donaldson, L. (1996). For Positivist Organisation Theory. London: Sage.

Doogan, K. (2001). 'Insecurity and long-term employment'. Work, Employment and Society, 15, 419-42.

Doogan, K. (2005). 'Long-term employment and the restructuring of the labour market mobility and job stability in Germany'. European Societies, 6, 48-70.

Dopson, S. and Stewart, R. (1990). 'What is happening to middle management?'. British Fournal of Management, 1, 3-16.

Drucker, P. (1992). 'The new society of organizations'. Harvard Business Review, September/October, 95-104.

Duberley, J., Cohen, L. and Mallon, M. (2006). 'Constructing scientific careers: change, continuity and context'. Organization Studies, 27, 1131-51.

Du Gay, P. (2005). The Values of Bureaucracy. Oxford: Oxford University Press.

Eaton, S. and Bailyn, L. (2000). 'Career as life path: tracing work and life strategies of biotech professionals'. In Peiperl, M., Arthur, M., Goffee, R. and Morris, T. (Eds), Career Frontiers: New Conceptions of Working Lives. Oxford: Oxford University Press, 177-98.

Eby, L. T., Butts, M. and Lockwood, A. (2003). 'Predictors of success in the era of the boundaryless career?'. Fournal of Organizational Behaviour, 24, 689-708.

Eisenhardt, K. (1989). 'Building theories from case study research'. Academy of Management Review, 14, 532-50.

Endo, K. (1998). 'Japanization of performance appraisal systems: a historical comparison of the American and Japanese systems'. Social Science Japan Foumal, 1, 247-62.

Ezzamel, M., Morris, J. and Smith, J. (2004). Accounting for New Organizational Forms: The Case of Subcontracting and Outsourcing. London: Association of Chartered Certified Accountants.

Farber, H. S. (1997). 'The changing face of job loss in the United States, 1981-93'. Brookings Papers on Economics Activity, Microeconomics Supplement, 55-142.

Farrell, G. and Morris, J. (2003). 'The neo-bureaucratic state: professionals, managers and professional managers in schools, general practices and social work'. Organization, 10, 129-56.

Farrell, C. and Morris, J. (2012). 'Managing in the neo-bureaucratic organization'. International fournal of Human Resource Management, forthcoming.

Fevre, R. (2007). 'Employment insecurity and social theory: the power of nightmares'. Work, Employment and Society, 21, 517-36.

Fine, B. (1998). Labour Market Theory: A Constructive Reassessment. London: Routledge.

Flick, U. (2006). An Introduction to Qualitative Research, 3rd edition. London: Sage.

Fournier, V. and Grey, C. (2000). 'At the critical moment'. Human Relations, 53, 7-32.

Gallie, D. and Paugam, S. (Eds) (2000). Welfare Programmes and the Experience of Unemployment in Europe. Oxford: Oxford University Press.

Gangl, M. (2004). 'Welfare states and the scar effects of unemployment: a comparative analysis of the United States and West Germany'. American fournal of Sociology, 109, 1319-64.

Genda, Y. (2005). A Nagging Sense of Job Insecurity: The New Reality Facing Japanese Touth. Tokyo: International House of Japan Press.

Giddens, A. (1990). The Consequences of Modernity. Cambridge: Policy Press, 56-109.

Giddens, A. (1994). 'Living in post-traditional society'. In Beck, U., Giddens, A. and Lash, S. (Eds), Reflexive Modernisation. Cambridge: Cambridge: University Press, 56-109.

Giddens, A. (2000). The Third Way and Its Critics. Cambridge: Polity Press.

Goldthorpe, J. (2002). 'Globalisation and social class'. Western European Politics, 3, 1-28.

Granrose, C. S. and Baccili, P. A. (2006). 'Do psychological contracts include boundaryless protean careers?'. Career Development International, 11, 163-82.

Grey, C. and Garsten, C. (2001). 'Trust, control and post-bureaucracy'. Organization Studies, 22, 229-50.

Grimshaw, D., Beynon, H., Rubery, J. and Ward, K. (2002). 'The restructuring of career paths in large service sector organizations: “delayering”, upskilling and polarisation'. Sociological Review, 50, 89-116.

Guest, D. and Mackenzie Davey, K. (1996). 'Don't write off the traditional career'. People Management, 22, 5.

Guillén, M. (2001). 'Is globalization civilizing, destructive or feeble? A critique of five key debates in the social science literature'. Annual Review of Sociology, 27, 235-60.

Gunz, H., Evans, M. and Jallano, M. (2000). 'Career boundaries in the "boundaryless" world'. In Peiperl, M., Arthur, M., Goffee, R. and Morris, T. (Eds), Career Frontiers: New Conceptions of Working Lives. Oxford: Oxford University Press, 24-53. 
Hales, C. (1999a). 'Leading horses to water? The impact of decentralization on managerial behaviour'. Fournal of Management Studies, 36, 831-51.

Hales, C. (1999b). 'Why do managers do what they do? Reconciling evidence and theory in accounts of managerial work'. British Fournal of Management, 10, 335-50.

Hales, C. (2002). 'Bureaucracy-lite and continuities in managerial work'. British fournal of Management, 13, $335-50$.

Hales, C. (2005). 'Rooted in supervision, branching into management: continuity and change in the role of the first-line manager'. Fournal of Management Studies, 42, 471-506.

Hall, D. T., Zhu, G. and Yan, A. (2002). 'Career creativity in protean identity transformation'. In Peiperl, M. A., Arthur, M. B. and Anand, N. (Eds), Career Creativity. Oxford: Oxford University Press, 385-92.

Hammer, M. and Champy, J. (1993). Reengineering the Corporation. New York: Harper Business.

Handy, C. (1995). The Empty Raincoat: Making Sense of the Future. London: Arrow Business.

Harris, M. and Höpfl, H. M. (2006). 'Introduction: organization in the age of post-bureaucracy'. Fournal of Organizational Change Management, 19, 5-7.

Harris, M., Clegg, S. and Höpfl, H. (2011). 'Introduction'. In Clegg, S., Harris, M. and Höpfl, H. (Eds), Managing Modernity: Beyond Bureaucracy? Oxford: Oxford University Press, 6-11.

Hassard, J., McCann, L. and Morris, J. (2009). Managing in the Modern Corporation: The Intensification of Managerial Work in the US, UK and Fapan. Cambridge: Cambridge University Press.

Heckscher, C. (1994). 'Defining the post-bureaucratic type'. In Heckscher, C. and Donnellon, A. (Eds), The Post-Bureaucratic Organization: New Perspectives on Organizational Change. London: Sage, 14-62.

Heckscher, C. (1995). White Collar Blues: Management Loyalties in an Age of Corporate Restructuring. New York: Basic Books.

Heckscher, C. and Adler, P. S. (2006). The Firm as a Collaborative Community. Oxford: Oxford University Press.

Heckscher, G. and Applegate, L. M. (1994). 'Introduction'. In Heckscher, C. and Donnellon, A. (Eds), The Post-Bureaucratic Organization: New Perspectives on Organizational Change. London: Sage, 1-13.

Heckscher, C. and Donnellon, A. (Eds) (1994). The Post-Bureaucratic Organization: New Perspectives on Organizational Change. London: Sage, 14-62.

Heery, E. and Salmon, J. (Eds) (2000). The Insecure Workforce. London: Routledge.

Ibarra, H. (2003). Working Identity: Unconventional Strategy for Re-Inventing Your Career. Boston, MA: Harvard Business School Press.

Ibarra, H. and Deshpande, P. M. (2007). 'Networks and identities: reciprocal influences and career processes and outcomes'. In Gunz, H. and Peiperl, M. (Eds), Handbook of Career Studies. London: Sage, 26882.

Inkson, K. (2006). 'Protean and boundaryless careers as metaphors'. Fournal of Vocational Behaviour, 69, 48-63.

Jacoby, S. (1985). Employing Bureaucracy: Managers, Unions and the Transformation of Work in American Industry, 1900-1945. New York: Columbia University Press.

Jacoby, S. (1999). 'Are career jobs headed for extinction?'. Califormia Management Reviere, 42, 123-45.

Jacoby, S. (2005). The Embedded Corporation: Corporate Governance and Employment Relations in Fapan and the United States. Princeton, NJ: Princeton University Press.

Johnson, P., Wood, G., Brewster, C. and Brookes, M. (2009). 'The rise of post-bureaucracy: theorists' fancy or organizational praxis?'. International Sociology, 24, 37-61.

Jones, C. (1996). 'Careers in project networks: the case of the film industry'. In Arthur, M. B. and Rousseau, D. M. (Eds), The Boundaryless Career: A New Employment Principle for a New Organisation Era. New York: Oxford University Press, 58-75.

Josserand, E., Teo, S. and Clegg, S. (2006). 'From bureaucratic to post-bureaucratic: the difficulties of transition'. Fournal of Organizational Change Management, 19, 54-65.

Kalleberg, A. L. (2003). 'Flexible firms and labour market segmentation: efforts of workplace restructuring on jobs and workers'. Work and Occupations, 30, 154-75.

Kalleberg, A. L., Reskin, B. and Hudson, E. (2000). 'Bad jobs in America: standard and non standard employment practices and job quality in the United States'. American Sociological Reviere, 65, 236-78.

Kanter, R. (1989). When Giants Learn to Dance. London: Simon and Schuster.

Kerckhoff, A. C. (1995). 'Institutional arrangements and stratification processes in industrial societies'. Annual Review of Sociology, 15, 323-47.

Khurana, R. (2004). Searching for a Corporate Savior: The Irrational Quest for Charismatic CEOs. Princeton, NJ: Princeton University Press.

King, Z. (2003). 'New or traditional career? A study of UK graduates preferences'. Human Resource Management Fournal, 13, 119-33. 
King, Z., Burke, S. and Pemberton, J. (2005). 'The bounded career: an empirical study of human capital, career mobility and employment outcomes in mediated labour markets'. Human Relations, 58, 9811007.

Kunda, G. (1992). Engineering Culture, Control and Commitment in a High-Tech Corporation. Philadelphia, PA: Temple University Press.

Lazarova, M. and Taylor, S. (2009). 'Boundaryless careers, social capital, and knowledge management: implications for organizational performance'. Fournal of Organizational Behavior, 30, 119-39.

Lincoln, J. and Nakata, Y. (1997). 'The transformation of the Japanese employment system: nature, depth and origins'. Work and Occupations, 24, 33-55.

Littler, C. and Innes, P. (2004). 'The paradox of managerial downsizing'. Organization Studies, 25, 1159 84.

Littler, C., Wiesner, R. and Dunford, R. (2003). 'The dynamics of delayering: changing management structures in three countries'. Fournal of Management Studies, 40, 225-56.

MacDuffie, J. P. (1996). 'Automotive white collar: the changing status and roles of salaried employees in the North American auto industry'. In Osterman, P. (Ed.), Broken Ladders: Managerial Careers in the New Economy. Oxford: Oxford University Press, 81-125.

Mainero, L. A. and Sullivan, S. E. (2006). The Opt-out Revolt: Why People Are Leaving Companies to Create Kaleidoscopic Careers. Mountain View, CA: Davies-Black.

Matanle, P. (2003). Japanese Capitalism and Modernity in a Global Era: Refabricating Lifetime Employment Relations. London: Routledge Curzon.

Mayrhofer, W., Meyer, M. and Steyrer, J. (2007). 'Contextual issues in the study of careers'. In Gunz, H. and Peiperl, M. (Eds), Handbook of Career Studies. London: Sage, 215-40.

McCann, L., Hassard, J. and Morris, J. (2004). 'Middle managers, the new organizational ideology and corporate restructuring: comparing Japanese and Anglo-American management structures'. Competition and Change, 8, 27-44.

McCann, L., Morris, J. and Hassard, J. (2008). 'Normalized intensity: the new labour process of UK middle managers after large scale restructuring'. Fournal of Management Studies, 45, 343-71.

McCann, L., Hassard, J. and Morris, J. (2010). 'Restructuring managerial labour in the USA, UK and Japan: challenging the salience of "Varieties of Capitalism"'. British Fournal of Industrial Relations, 48 , 347-74.

McKinlay, A. (2002). " "Deadselves": the birth of the modern career'. Organization, 9, 595-614.

McSweeney, B. (2006). 'Are we living in a post-bureaucratic epoch?'. Journal of Organizational Change Management, 19, 22-37.

Miles, R. E. and Snow, C. C. (1996). 'Twenty-first century careers'. In Arthur, M. B. and Rousseau, D. M. (Eds), The Boundaryless Career. Oxford: Oxford University Press, 95-115.

Mintzberg, H. (1973). The Nature of Managerial Work. New York: Harper and Row.

Monk, A. H. B. (2009). 'The financial thesis: reconceptualizing globalization's effect on firms and institutions'. Competition \& Change, 13, 51-74.

Morris, M. and Western, B. (1999). 'Inequality in earnings at the close of the twentieth century'. Annual Review of Sociology, 59, 205-19.

Morris, J., Hassard, J. and McCann, L. (2006). 'New organizational forms, human resource management and structural convergence? A study of Japanese organizations'. Organization Studies, 27, 1485-512.

Morris, J., Hassard, J. and McCann, L. (2008). 'The resilience of "institutionalised capitalism": managing under "shareholder capitalism" and "managerial capitalism". Human Relations, 61, 687-710.

Mythen, G. (2005). 'Employment: individualization and insecurity: rethinking the risk society perspectives'. Sociological Review, 53, 272-950.

Nicholson, N. (1995). 'Career systems in crisis: change and continuity in the information age'. Academy of Management Executive, 10, 40-51.

Okubayashi, K. (1998). 'Small headquarters and the reorganization of management'. In Harukiyo, M. and Hook, G. (Eds), Japanese Business Management: Restructuring for Low Growth and Globalization. London: Routledge, 163-92.

O'Reilly, C. A. and Pfeffer, J. (2000). Hidden Value: How Great Companies Achieve Extraordinary Success. Boston, MA: Harvard University Press.

Osterman, P. (Ed.) (1996). Broken Ladders: Managerial Careers in the New Economy. New York: Oxford University Press.

Osterman, P. (2009). The Truth about Middle Managers. Boston, MA: Harvard Business School Press.

Osterman, P., Kochan, L., Locke, R. M. and Piore, M. (2001). Working in America: A Blueprint for a New Labour Market. Cambridge, MA: MIT Press. 
Peiperl, M. and Baruch, Y. (1997). 'Back to square zero: the post-corporate career'. Organization Dynamics, 25, $7-22$.

Peiperl, M., Arthur, M. B., Goffee, R. and Morris, T. (Eds) (2000). Career Frontiers: New Conceptions of Working Lives. New York: Oxford University Press.

Peters, T. J. (1992). Liberation Management. New York: Macmillan.

Pettigrew, A. and Fenton, E. (2000). The Innovating Organisation. London: Sage.

Pfeffer, J. (1997). New Directions for Organization Theory. New York: Oxford University Press.

Pfeffer, J. (1998). 'Seven practices of successful organizations'. California Management Revierw, 40, 96124.

Pfeffer, J. (2007). 'Human resources from an organizational behavior perspective: some paradoxes explained'. Fournal of Economic Perspectives, 21, 115-34.

Porras, J. and Silvers, R. (1991). 'Organization development and transformation'. Annual Review of Psychology, 42, 51-78.

Pringle, J. K. and Mallon, M. (2003). 'Challenges for the boundaryless career odyssey'. International Fournal of Human Resource Management, 14, 838-53.

Reed, M. and Ezzamel, M. (2008). "Introduction", Special issue on "Governance in transition? Emerging Paradigms and Practices for the 21st Century"'. Human Relations, 61, 595-6.

Roper, J., Ganesh, S. and Inkson, K. (2011). 'Neoliberalism and knowledge interests in boundaryless careers discourse'. Work, Employment and Society, 24, 661-79.

Royal, C. and Althauser, R. P. (2003). 'The labour markets of knowledge workers: investment bankers' careers in the wake of corporate restructuring'. Work and Occupations, 30, 214-33.

Schmidt, S. R. (2000). 'Job security beliefs in the general social survey: evidence of long-run trends with other surveys'. In Neumark, D. (Ed.), On the Fob: Is Long-Term Employment a Thing of the Past?. New York: Russell Sage Foundation, 87-106.

Scott, E. D., O'Shaughnessy, K. and Cappelli, P. (1996). 'Management jobs in the insurance industry: organizational deskilling and rising pay inequity'. In Osterman, P. (Ed.), Broken Ladders: Managerial Careers in the New Economy. New York: Oxford University Press, 126-54.

Sparrow, P. R. (1996). 'Transitions in the psychological contract: some evidence from the banking sector'. Human Resource Management Fournal, 6, 75-92.

Sturges, J. and Guest, D. (2001). 'Don't leave me this way: a qualitative study of influences on the organizational commitment and turnover intentions and graduates early in their career'. British fournal of Guidance and Conselling, 20, 447-62.

Sturges, J., Guest, D. and Mackenzie Davey, K. (2000). 'Who's in charge? Graduate attitudes to and experiences of career management and their relationship with organizational commitment'. European Fournal of Work and Organizational Psychology, 9, 35-70.

Tams, S. and Arthur, M. B. (2007). 'Studying careers across cultures: distinguishing international, cross cultural and globalization perspectives'. Career Development International, 12, 86-98.

Tempel, A. and Walgenbach, P. (2007). 'Global standardization of organizational forms and practices? What new institutionalism and the business systems approaches can learn from one another'. Fournal of Management Studies, 44, 1-24.

Tempest, S., McKinlay, A. and Starkey, K. (2004). 'Careering alone: careers and social capital in the financial services and television industries'. Human Relations, 57, 1523-45.

Tengblad, S. (2006). 'Is there a "new managerial work"? A comparison with Henry Mintzberg's classic study 30 years later'. Fournal of Management Studies, 43, 1437-61.

Thomas, D. C. and Inkson, K. (2007). 'Careers across countries'. In Gunz, H. and Peiperl, M. (Eds), Handbook of Career Studies. London: Sage, 451-70.

Turnbull, P. and Wass, V. (2000). 'Redundancy and the paradox of job insecurity'. In Heery, E. and Salmon, J. (Eds), The Insecure Workforce. London: Routledge, 57-77.

Turner, B. (1972). Exploring the Industrial Subculture. New York: Herder and Herder.

Useem, M. (1999). Investor Capitalism: How Money Managers Are Rewriting the Rules of Corporate America. New York: Basic Books.

Usui, C. and Colignon, R. (1996). 'Corporate restructuring: converging world pattern or societally specific embeddedness?'. Sociological Quarterly, 4, 351-78.

Van Maanen, J. (2006). 'Rediscovering Japan: some thoughts on change and continuity in traditional Japanese careers'. Career Development International, 11, 280-92.

Van Maanen, J. (2011). 'Ethnography as work: some rules of engagement'. Fournal of Management Studies, 48, 218-34.

Watson, T. (1994). In Search of Management. London: Routledge. 
Watson, T. (2011). "Ethnography, reality and truth: the vital need for studies of "how things" work in organizations and management'. Fournal of Management Studies, 48, 202-17.

Webb, J. (2004). 'Organizations, self-identities, and the new economy'. Sociology, 38, 719-38.

Weick, K. (1996). 'Enactment and the boundaryless career: organising as we work'. In Arthur, M. B. and Rousseau, D. M. (Eds), The Boundaryless Career. Oxford: Oxford University Press, 40-57.

Worrall, L. and Cooper, C. (2001). The Quality of Working Life: The 2000 Survey of Managers' Experiences. London: Institute of Management.

Zabusky, S. and Barley, S. (1996). 'Redefining success: ethnographic observations on the careers of technicians'. In Osterman, P. (Ed.), Broken Ladders: Managerial Careers in the New Economy. New York: Oxford University Press, 185-214.

Zaleska, K. J. and de Menezes, L. M. (2007). 'Human resources development practices and their association with employee attitudes: between traditional and new careers'. Human Relations, 60, 987-1018. 